\title{
Call for risk/benefit study of gene therapy
}

Paris. The group that advises the European Commission on ethical questions related to biotechnology has called on the commission to make basic and clinical research in gene therapy a "priority". Its recommendation is part of a opinion on gene therapy made public last week in the presence of Jacques Delors, the outgoing commission president at a press conference in Brussels.

But the group also says that more attention should be paid to evaluating the risks and efficacy of the technology. The current publicity about somatic gene therapy trials risks "misleading the public", says Noelle Lenoir, the chairwoman of the group and a member of the French constitutional council.

"What we are saying is that gene therapy is a promising technology, so let's go for it," says Lenoir. "But let's remember it's still an experimental technology, so don't give false hopes, and be prudent at the research and clinical level." A full review of clinical trials already under way should be made public, she says, in order to provide a "realistic assessment" of the risks and state of the technology currently available.

Lenoir argues that the tendency of some researchers to encourage "excessive" publicity about gene therapy has also been responsible for overreaction - both for and against gene therapy - among decisionmakers, and risks altering the "prudence and rigour" of the scientific approach.

She also claims that trials are often "more medical than scientific", and often depend on small amounts of preclinical data, in particular when trials involve terminally ill patients. This narrow approach leads to neglect of the wider social issues raised concerning the social implications of individuals whose genes have been modified.

To correct such trends, the group recommends that national supervisory bodies make public regular assessments of continuing trials. It also calls for standardized European guidelines for good practice in gene therapy, with the European Medicines

\section{US to cut applied energy research}

Washington. The US Department of Energy (DoE) is to bear almost half of the \$24 billion, five-year budget cutting package proposed by President Bill Clinton on Monday. $\$ 1.2$ billion of the savings will come from the department's applied research programme.

The cuts in applied research will be spread across a range of programmes, including nuclear fusion, nuclear fission, solar power and energy conservation. Department officials said that the $\$ 40$ million-a-year clean coal programme will be closed as ongoing projects in it are completed.

Other programme closures have not been specified. The department has merely said that the money will be found from cuts in its applied research programmes, and through cost-sharing and cuts in "lower priority programmes."

Bill White, the deputy energy secretary, said that decisions over whether to close any of the DoE's national laboratories would await the verdict of a panel chaired by Bob Galvin, former chairman of Motorola, which will report on the future of the laboratories in February.

A more detailed picture of the cuts will emerge on the return of Hazel O'Leary, the energy secretary, from a trip to Europe. But full details will not be released until Clinton publishes his budget proposals in early February. Some observers predict that few cuts will be specified even then, as most of these are likely to fall toward the end of the five year period.

The $\$ 1.2$ billion to be cut from $\mathrm{DoE}$ research will come from energy supply, fossil energy and energy conservation work, department officials said. Their largest and most vulnerable elements include solar energy ( $\$ 251$ million this year), fossil energy research (\$352 million) and magnetic fusion ( $\$ 363$ million). D0E basic research, such as high energy physics and nuclear physics programmes, are not affected by the proposed cut.

Charles Curtis, the assistant energy secretary, last week issued a flat denial of reports that the Princeton Plasma Physics Laboratory (PPPL) in New Jersey, which performs much of the fusion programme, was to close. Rumours persist that at least one DoE lab will shut. But White insisted that "we haven't identified any particular facility to be closed."

The largest cuts will fall on the DoE's \$7 billion-a-year programme to clean up its nuclear sites. White said savings would come from subcontracting work to the private sector, although most is already done by contractors, and observers expect the cuts to further slow down the already glacial cleanup process.

Clinton's \$24 billion cuts package will pay for one-third of the middle-class tax cut which he promised the American people in a televised broadcast last week: the other two-thirds are to be paid for by extending an existing budget freeze out from 1999 to 2001. The package is seen as the starting point in a bidding war between the administration and the new Republican majority in Congress, in which the Republicans are likely winners and the science budget is a certain loser.

Colin Macilwain
Agency as an appropriate focus, and recommends that Europe-wide evaluations of the risks and results of gene therapy technology should be published regularly.

The group is also concerned that existing European Union (EU) legislation on the safety of genetically modified organisms (GMOs) is inadequate with respect to gene therapy. In particular, it claims that the wording of the two directives on the contained use and environmental release of such organisms means that the directives are not applicable to gene therapy. The commission should amend them to include a specific reference to gene therapy, says Lenoir.

Because of the uncertainty of the risks of somatic gene therapy, the group also recommends that it be restricted to serious diseases for which no other treatment is available. Widening to other "therapeutic" applications, it says, should be considered only after a case-by-case medical and ethical analysis, it says.

The group says that human germline gene therapy "is not ethically acceptable at the present time" given the "important controversial and unprecedented" questions it raises.

This compromise formula - which accommodates both those who seek a moratorium on such techniques and those who consider a ban premature and unnecessary - reflects a growing belief that this debate serves little purpose other than to detract attention from the more immediate and tangible problems of somatic gene therapy.

The opinion also recommends that Europe should establish the equivalent of the US Orphan Drugs Act, which provides commercial and legal incentives to companies that develop drugs for rare diseases. This reflects concern that gene therapy will eventually be used mainly for common diseases such as cancer and AIDS, and that pharmaceutical companies will abandon research into rarer diseases because it is no longer profitable.

But Lenoir says the main aim of this recommendation is formally to introduce the notion of equal access to therapies as an ethical issue. She points out that the group has the right to demand this from the commission, given that article 129 of the Maastricht treaty gives the commission a mandate to guarantee fair allocation of health-care resources.

The group is trying to shake off the accusation that it was set up by the commission only to confer legitimacy on the commission's often controversial biotechnology policies. Lenoir admits this perception exists, and is keen that the group should build a reputation as an independent watchdog.

Declan Butler 